\title{
Lateral
}

Journal of the Cultural Studies Association

\section{What is Whiteness in North Africa?}

by Leila Tayeb | Cultural Constructions of Race and Racism in the Middle East and North Africa / Southwest Asia and North Africa (MENA/SWANA), Issue 10.1 (Spring 2021)

\begin{abstract}
This entry sketches a matrix for conceptualizing race in/ and North Africa that takes Arabness, indigeneity, Islam, the Sahara, and slavery as orienting keywords. It suggests an approach to a geopolitically-grounded whiteness as social currency and aspiration that is both based in specific regional economic history and also reaches outward toward globally-circulating formations of racial hierarchy. Acknowledging the distinct legal, colonial, and state histories under and through which racialization has proceeded in North and Saharan Africa since the dissolution of the Ottoman Empire, this entry aims to draw out the ethical imaginaries through which bodies have been marked and categorized in this region. These ethical imaginaries have operated through their attendant languages, memories, and performances to enable racisms and colorisms with violent and enduring material consequences. Under the headings "Racialized Enslavement," "Whiteness and Arabness," "Race and the Sahara," and "Race in North African Popular Culture," I offer brief introductions to these discursive formations, histories, and conceptual intersections and offer suggested readings for each.
\end{abstract}

KEYWORDS anti-Blackness, Arabness, Blackness, indigeneity, Islam, North Africa, slavery, whiteness

On the second day of Ramadan, in early May of 2019, the Doha-based television channel Libya al-Ahrar aired an episode of its hidden camera program in which the show's star prankster blackens her face, adopts mocking versions of a "Sudanese" accent and attire, and then traps strangers in an elevator with two monkeys that she insistently describes as her children.1 Only a few days later, the show repeated the blackface gag. This time the actor asks the waiter in a Lebanese restaurant in Libya to read the menu line by line with her as she responded with outrageous incomprehension, confusing things like "juice box" to exclaim, "You have dog juice?!" The elevator episode circulated on social media platforms with some condemnation but remains available on YouTube; the restaurant episode seemingly aired without hesitation. The ostensible comedy in these depictions relies on anti-Black racism and, in so doing, functions to ratify discourses of white supremacy. Like blackface performance practices elsewhere, these depictions reveal much more about those creating and consuming the racist portrayals than about those supposedly being portrayed. In these Libyan hidden camera clips and elsewhere in North African popular culture, who are the "white" Arabic-speakers that these racist depictions aim to elevate? What is whiteness in this context?? 


\section{Images of blackface performance from a Libyan hidden camera show.}

In this short piece, I offer a reading list for thinking about whiteness in North Africa. By gathering the current literature, I posit Islam, slavery, indigeneity, Arabness, and the Sahara as orienting keywords in order to sketch a matrix for conceptualizing race in/and North Africa. I suggest that we must attend to a geopolitically-grounded whiteness operating in northern Africa as social currency and aspiration. By this I mean a notion of whiteness that is both based in specific regional economic and social history and also reaches outward toward globally circulating formations of racial hierarchy. Acknowledging the distinct legal, colonial, state histories under and through which racialization has proceeded in North and Saharan Africa since the decline and dissolution of the Ottoman Empire, this entry draws out the ethical imaginaries through which bodies have been marked and categorized in this region. $\frac{3}{-}$ These ethical imaginaries operate through their attendant languages, memories, and performances to enable racisms and colorism with violent and enduring material consequences.

Through and alongside this matrix of keywords, I make two claims. The first is that there is analytical purchase to thinking whiteness in and through North Africa, even while this formation of whiteness only partially overlaps with the more dominant formations of whiteness attendant to and produced by European colonialism. The second is that through a range of discourses and performances in both scholarship and popular culture, Blackness is repeatedly constructed as if it were non-indigenous to North Africa. Ironically, this latter discursive practice is among a number of those which, as Jemima Pierre has argued, "actually work to impede race analysis about the African continent (beyond southern Africa), entrapping us into a kind of race-blindness." 4 The North versus SubSaharan Africa divide, Pierre continues, "has shaped Africanist scholarship to the point that this distinction is often assumed rather than interrogated." -5 This naturalized division is racialized: colonial scholars painted light-skinned people of the southern Mediterranean as "closer" to Europe both geographically and in terms of civilization. By continuing to describe North Africa as inevitably distinct from "Black Africa," we not only reinscribe this violent hierarchy, but we also prevent ourselves from seeing racialization as processual and dynamic. In so doing, we miss the opportunity to understand North and Saharan African spaces as sites for the ongoing production of race and white supremacy.

To offer a starting place-in a 1967 article, historian Leon Carl Brown described North Africa as "the great border zone where white ends meeting the area where black begins," 
where, he contended, "native whites and native blacks have confronted each other since the beginning of history." 6 Brown's essay goes on to incorporate a number of the key terms that I propose here, and compellingly illuminates a period of early postcolonial African hope and its emerging challenges by describing the ambivalent Pan-Africanism of Gamal Abdel Nasser and others in the 1950s and 1960s. But this formulation of a "great border zone" aptly illustrates the racialization of naturalized geography which has long characterized colonial (and some earlier) descriptions of northern Africa. When we take for granted the idea that the Sahara constitutes a natural border, we reify a logic that posits racial whiteness as indigenous to North Africa, racial Arabness as contributing to the maintenance of that whiteness, and racial blackness as non-indigenous. Amazigh ("Berber") indigeneity is here simultaneously configured as racially white and erased insofar as indigenous modes of thinking difference are domesticated.

Here, and in my research on contemporary Libya, I am invested in understanding whiteness not as a static ontology but as "a problematic, or an analytical perspective: that is, a way of formulating questions about social relations." "- Thinking in terms of both conceptual and embodied movement, I am especially interested in "the ways that whiteness seduces and rewards, becoming the subject of fantasy and desire," ${ }^{8}$ and I agree with Steve Garner that "the best way to understand whiteness is to think both relationally and comparatively." -9 In Garner's work and in more recent scholarship, this has primarily meant taking the critical study of whiteness beyond its "home" of the United States and into Europe, Australia, and New Zealand. What happens when we take this study from settler colonial contexts into the postcolony? To turn again to Pierre, "how could any postcolonial society not be structured by its legacy of race and racialization-especially when colonialism was, in the most ideological, political, and practical way, racialized rule? How do we, in fact, analyze the persistence of white (and racialized Arab) privilege in postcolonial spaces?"므

Whiteness is both productive and the product of affective force, and while it moves, it moves us. As Sara Ahmed has argued, "Whiteness could be described as an ongoing and un-finished history, which orientates bodies in specific directions, affecting how they 'take up' space."'11 My argument here is not that (some) North Africans are in any stable sense white or have access to the top rungs of global hierarchies of white supremacy. Rather, I am interested in the array of things that formations of whiteness do and enable in the contexts of northern Africa. 12 Whiteness shapes both how bodies can take up space and what spaces are available to whom. As Ahmed writes,

If the world is made white, then the body-at-home is one that can inhabit whiteness. As Fanon's work shows, after all, bodies are shaped by histories of colonialism, which makes the world 'white', a world that is inherited, or which is already given before the point of an individual's arrival. This is the familiar world, the world of whiteness, as a world we know implicitly. Colonialism makes the world 'white', which is of course a world 'ready' for certain kinds of bodies, as a world that puts certain objects within their reach. $\underline{13}$

Ahmed is not describing North Africa here (even while a trace of North Africa haunts this passage with Fanon). But the "bodies-at-home" in North Africa are most often those that can inhabit whiteness. As I suggest above, both Western scholarship and local discursive practices make North African spaces white. In this way, whiteness in North Africa takes valences of "Europeanness," as a colonial remnant, while it also operates in another register, as "our own" whiteness, a color-coded language of virtue and status. This 
includes but is not reducible to white-as-Western because a local articulation of whiteness can be valorized at the same time that Westernness is rejected. This local articulation of whiteness is bound up in histories that stretch back at least as far the seventh-century Arab invasion of North Africa.

This entry proceeds by pairing and working through the orienting keywords of Arabness, indigeneity, Islam, the Sahara, and slavery to outline the frameworks and problematics these themes suggest for thinking whiteness in North Africa. Under the headings "Racialized Enslavement," "Whiteness and Arabness," "Race and the Sahara," and "Race in North African Popular Culture," I offer brief introductions to these discursive formations, histories, and conceptual intersections and offer suggested readings for each. Some of the relevant literatures have not, to my knowledge, substantively engaged each other, yet reading across these separate conversations will be necessary as we build tools for understanding race in northern Africa.

\section{Racialized Enslavement}

Blackness is produced as non-indigenous to North Africa through a racial imaginary that relies on the histories of racialized enslavement that have characterized the region. To offer an incomplete list, the slave trade was officially outlawed in Tunisia in 1841, 14 in Algeria in 1848, $\frac{15}{1}$ in Libya in 1856, 16 in Egypt in 1887, 17 in Morocco in 1923, $\frac{18}{-}$ and in

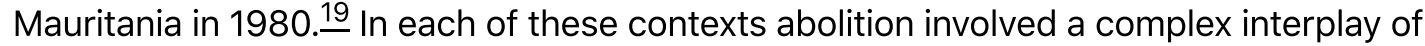
colonial politics with regional and local discourses and economic forces; in most cases the practice continued for decades after its legal prohibition. The slave trades that moved across the Sahara, the Red Sea, and the Mediterranean Sea involved captives of a range of geographic and ethnic backgrounds, and, as a number of historians have shown, frequently were justified through moral-legal formations that marked non-Muslims as enslavable. $\frac{20}{\text { Yet}}$, historians have also illustrated how enslavement came to be specifically articulated to a conception of blackness in these regions, producing a racialized distinction. John Hunwick, for example, argued that from the sixteenth century onward in the "Mediterranean Islamic world," blackness became associated with slavery by virtue of

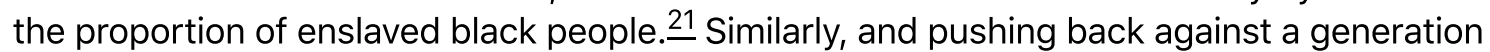
of scholarship which described "Islamic slavery" as a relatively "benign" institution, Chouki El Hamel more recently argued "that relying solely on Islamic ideology as a crucial key to explain social relations, particularly in the history of black slavery in the Muslim world, yields an inaccurate historical record of the people, institutions, and social practices of slavery in the Arab world." 22 In the context of North Africa, broadly, the production of a category of blackness linked to enslavement and arrival also enabled the production of a formation of whiteness linked to Arabness, superiority, and normative belonging.

Suggested reading (in order of publication date):

- John Hunwick and Eve Troutt Powell, eds., The African Diaspora in the Mediterranean Lands of Islam (Princeton: Markus Wiener Publishers, 2002).

- Terence Walz and Kenneth Cuno, eds., Race and Slavery in the Middle East: Histories of Trans-Saharan Africans in Nineteenth-Century Egypt, Sudan, and the Ottoman Mediterranean (Cairo: American University in Cairo Press, 2010).

- Eve Troutt Powell, Tell This in My Memory: Stories of Enslavement from Egypt, Sudan, and the Ottoman Empire (Stanford: Stanford University Press, 2012). 
- Ismael Montana, The Abolition of Slavery in Ottoman Tunisia (Gainesville: University Press of Florida, 2013).

- Chouki El Hamel, Black Morocco: A History of Slavery, Race, and Islam (New York: Cambridge University Press, 2013).

- Timothy Cleaveland, "Ahmad Baba al-Timbukti and his Islamic Critique of Racial Slavery in the Maghrib," Journal of North African Studies 20, no. 1 (2015): 42-64.

- Amal Altaleb, "The Social and Economic History of Slavery in Libya (1800-1950)" (PhD diss., University of Manchester, 2015).

- Mahmood Mamdani et al., "Trans-African Slaveries," Comparative Studies of South Asia, Africa, and the Middle East 38, no. 2 (August 2018): 185-329.

- Erin Pettigrew, "Histories of Race, Slavery, and Emancipation in the Middle East," Mediterranean Politics 25, no. 4 (2020): 528-536.

\section{Whiteness and Arabness}

The legal and social histories of Arab attempts to varyingly claim and disavow whiteness in the United States have received substantive scholarly attention. These studies have illustrated how nineteenth- and early twentieth-century legal claims to whiteness by Arab immigrants were structured by the particular racial and legal regimes of their time. Primarily Christian immigrants who had come from greater Syria litigated claims to their whiteness as the route to naturalization in a period of Asian exclusion. This history is particular and contingent; that is to say, it might, in different circumstances, have been otherwise. $\frac{23}{}$ Even while describing a US context, such studies are relevant for conceptualizing whiteness in North Africa insofar as they enable us to observe some key aspects of the overlapping problematics at play between these two geopolitical sites, as well as the limitations of this overlap. Histories of Arab racialization in the US inflect globally circulating racial discourses. Further, even in a more contemporary US political context, one in which many Arab Americans do not actively seek access to whiteness, we find some popular and even scholarly articulations of Arabness that specifically occlude blackness. One finds this occlusion in, for example, discussions of shifting Arab American inclusion in whiteness, which leave out Black Arab Americans for whom whiteness has never been accessible.

Historians have also traced notions of Arabness as whiteness in other geopolitical and historical contexts. Ibn Battuta, for example, wrote in the mid-fourteenth century of "whites" as he traveled through the West African Sahel and southern Sahara; for him these included Arabs and Arabophone North Africans, but not Berbers, whose "distance and foreignness from the normative cultural practices of the Arab Muslim World" precluded whiteness. $\frac{24}{-E l ~ H a m e l ~ d e m o n s t r a t e s ~ t h a t ~ t h i s ~ f o r m u l a t i o n ~ o f ~ " w h i t e " ~ A r a b n e s s ~ m a y ~ h a v e ~}$ included people of a variety of family lineages, so long as they could claim "one drop" of (paternal) "Arab blood." 25 Pre-colonial Arab and Arabophone social formations did not necessarily value whiteness in terms of color and in terms of Europeanness in the same way that these come to be valued through empire, but Arabophone anti-blackness is

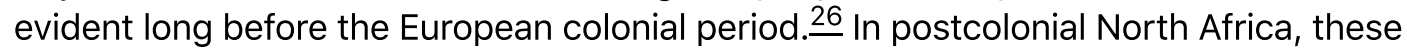
intertwined legacies have enabled outcomes like that described by Afifa Ltifi in Bourguiba's Tunisia, where colorblind family name policies constructed a normative whiteness and "reproduced the patron client relationships that bound slave and master's descendants." 27 Across contexts, "Arab" proximity to and approximation of whiteness has historically been predicated on anti-blackness. $\underline{28}$ 
Suggested reading:

- Helen Hatab Samhan, "Not Quite White: Race Classification and the Arab-American Experience," in Arabs in America: Building a New Future, ed. Michael Suleiman (Philadelphia: Temple University Press, 1999), 209-226.

- Bruce Hall, "The Question of 'Race' in the Pre-Colonial Southern Sahara," Journal of North African Studies 10, no. 3-4 (2005): 339-367.

- Amaney Jamal and Nadine Naber, eds., Race and Arab Americans Before and After 9/11: From Invisible Citizens to Visible Subjects (Syracuse: Syracuse University Press, 2008).

- Sarah Gualtieri, Between Arab and White: Race and Ethnicity in the Early Syrian American Diaspora (Berkeley: University of California Press, 2009).

- Amina Zarrugh, "Racialized Political Shock: Arab American Racial Formation and the Impact of Political Events," Ethnic and Racial Studies 39, no. 15 (2016): 2722-2739.

- Loubna Qutami, "Censusless: Arab/Muslim Interpolation into Whiteness and the War on Terror," Journal of Asian American Studies 23, no. 2 (June 2020): 161-200.

- Afifa Ltifi, "Black Tunisians and the Pitfalls of Bourguiba's Homogenization Project," POMEPS Studies 40 (June 2020): 69-72.

\section{Race and the Sahara (Arabs and Africans)}

Colonial representations in scholarship and popular media which utilize an oppositional framework for understanding "North Africa" as distinct from "Sub-Saharan Africa" suggest a racialized boundary of naturalized geography in the desert. A wave of scholarship in recent decades has attempted to alter this paradigm, describing the desert as a "bridge," 29 and honing in on Saharan and "trans-Saharan" histories and lifeworlds. $\frac{30}{2}$ Some of this work has illuminated the racialization that continues to adhere in the Arabophone states of the Mediterranean coast to the descendants of enslaved peoples captured in West Africa and other places. This racialization, as I describe above, posits blackness as a referentiality to enslavement which sticks to an array of bodies, including those of more recent migrants and indigenous Black North Africans. One result of this is the carving away of indigeneity from Black North Africans. By linking blackness to enslavement, this discourse in both scholarship and popular practice dispossesses Black North Africans of a natal claim to North Africa (and in some instances Arab identity) apart from a history of arrival. 31 If, as Sara Ahmed has argued, "whiteness becomes worldly through the noticeability of the arrival of some bodies more than others," distortion that contributes to the (re)production of whiteness in/as North Africa. $\underline{33}$

One of the quotidian ways these racial geopolitics are maintained is through the common third-person descriptor of Black people in northern Africa as "Africans" distinct from an unspecified (unmarked) norm. This discursive practice also produces a tension-filled and ambivalent whiteness, one with which Algerian diasporic activist Houria Bouteldja recently danced in a polemic on "whites, Jews, and us," when she wrote, "Fifty years after the independence movements, North Africa is the one subduing its own citizens and black Africans. I was going to say 'my African brothers.' But I no longer dare to, now that I have admitted my crime. Farewell Bandung." 34 In "no longer daring" to claim fraternal kinship, Bouteldja acknowledges the violence of North African anti-blackness. Yet, even then, in describing "North Africa" as "subduing its own citizens and black Africans," she also seems to suggest that the end of the colonially constructed state system could end North African anti-blackness. But the latter runs far deeper than the postcolonial state. North 
African unmarked whiteness itself holds up the "and" in her phrase, "its own citizens and black Africans."

Suggested reading:

- Eve Troutt Powell, A Different Shade of Colonialism: Egypt, Great Britain, and the Mastery of the Sudan (Berkeley: University of California Press, 2003).

- John Hunwick, "A Region of the Mind: Medieval Arab Views of African Geography and Ethnography and Their Legacy," Sudanic Africa 16 (2005): 103-136.

- Ghislaine Lydon, "Writing Trans-Saharan History: Methods, Sources, and Interpretations Across the African Divide," Journal of North African Studies 10, no. 3-4 (2005): 293324.

- E. Ann McDougall, "Constructing Emptiness: Islam, Violence and Terror in the Historical Making of the Sahara," Journal of Contemporary African Studies 25, no. 1 (2007): 17-30.

- Ziad Bentahar, "Continental Drift: The Disjunction of North and Sub-Saharan Africa," Research in African Literatures 42, no. 1 (Spring 2011): 1-13.

- Bruce Hall, A History of Race in Muslim West Africa, 1600-1960 (New York: Cambridge University Press, 2011).

\section{Race in North African Popular Culture}

If whiteness needs maintenance to persist and racializations of all sorts are continually unfolding, popular culture is a privileged site in which this work occurs, as is evident across this forum. In film, performance, visual art, and literature, representations mark bodies in and out of normative community, naturalize racialized language, entrench stereotypical figurations, and reify social hierarchies. Recent years have seen greater public controversies appear surrounding racist representations of Black characters in North African (and other Arab) popular culture. $\frac{35}{3}$ Scholarship investigating race and popular culture in/and North Africa is relatively emerging, but has tackled a range of themes and questions surrounding nationalism, empire, alterity and aesthetics across performance forms in the nineteenth and twentieth centuries. Continued work is needed. As of yet, scholars have more vigorously illustrated and theorized anti-black discourses, practices, and representations in popular culture than they have asked how these works produce and maintain whiteness. Complementary to this continuing work, I call for, and I hope to contribute to an inquiry into how numerous popular cultural forms have variously proposed, constructed, reified, subverted, and challenged North African iterations of normative whiteness.

Suggested reading:

- Eve Troutt Powell, "Burnt-Cork Nationalism: Race and Identity in the Theater of 'Ali alKassar," in Colors of Enchantment: Theater, Dance, Music, and the Visual Arts of the Middle East, ed. Sherifa Zuhur (Cairo: American University in Cairo Press, 2001), 13-26.

- Jessica Winegar and Katarzyna Pieprzak, eds, Critical Interventions: Africanity and North Africa (2009).

- Richard Jankowsky, Stambeli: Music, Trance, and Alterity in Tunisia (Chicago: University of Chicago Press, 2010).

- Ismael Montana, "Bori Practice Among Enslaved West Africans of Ottoman Tunis: Unbelief (Kufr) or Another Dimension of the African Diaspora?" History of the Family 16, no. 2 (June 2011): 152-159. 
- Ifdal Elsaket, "Jungle Films in Egypt: Race, Anti-Blackness, and Empire," Arab Studies Journal 25, no. 2 (Fall 2017): 8-32.

- Sophia Azeb, "The Pharoah's New Clothes," Chimurenga (July 2019).

- Cynthia Becker, Performing Blackness in Morocco: Gnawa Music and Visual Culture (Minneapolis: University of Minnesota Press, 2020).

\section{Conclusion}

Describing blackface performance in early twentieth-century Egypt, Eve Troutt Powell wrote of songs and plays in which "Nubian" ("berberi") and "Sudanese" characters enacted Egyptian anticolonial, nationalist desires. As she explained, "In the absence of the 'right' kind of Sudanese political allies - that is, those who would proclaim a desire for the unity of the Nile Valley-the Egyptian artists and writers deeply involved in the promulgation of the nationalist message made up their own Sudanese." ${ }^{\prime 36}$ The Libyan hidden camera skits with which I opened this writing, and which drew directly from this long history of Egyptian caricatures of Sudanese people, illustrate the continued need to interrogate the racial work that blackface and other performance practices do in North African contexts. Through violently erasing the Others they purport to represent, both a century ago and in the recent past these practices have served to construct their performers' and audiences' visions of themselves. They utilize anti-black tropes to produce whiteness in their performers, audiences, and cultural milieus. In this way, they join myriad other discursive and performative practices that repeatedly construct blackness as not indigenous to North Africa. It is imperative that we do not stop at noting the anti-black racism that we rightly see in these, but rather go on additionally to theorize the racial and spatial whiteness that these practices enable and uphold.

\section{Notes}

1. On this incident and for a link to the clip on YouTube, see Declan Walsh, "Blackface, Staple of Arab Comedy, Faces Surge of Criticism," New York Times, August 18, 2019, https://www.nytimes.com/2019/08/18/world/middleeast/blackface-arab-tv-racist.html < https://www.nytimes.com/2019/08/18/world/middleeast/blackface-arab-tv-racist.html>.

2. While much of what I write here is relevant to other parts of the MENA/SWANA region, including the Levant and the Gulf, I focus here on North Africa in order to address the particularities of trans-Saharan slavery and questions of indigeneity in Africa.

3. One major difference in colonial regimes of racialization between North Africa and the Levant has to do with how and when control transferred from Ottoman to European power. Territories in the Levant transferred after World War I were classified in "civilizational capacity" through the League of Nations Mandate system, which ranked Arab former provinces of the Ottoman Empire (racially) above former German colonies in Africa and the Pacific. The Ottoman periphery in North Africa moved to European control earlier-Italy invaded Libya in 1911; France established its protectorate in Tunisia in 1881, having occupied Algeria from 1830-and was subject to racial policies that stemmed from the colonial discourses of those competing powers. In Libya, for example, the Italian colonial "fourth shore" argument narrated North African ("Mediterranean") racial proximity in contrast to its holdings in East Africa, and in a way that dovetailed with preexisting notions of "Sudanese" black people found in Libya as inherently originating elsewhere. On the racializing power of the Mandate system, see Sherene Saikaly, "The Matter of Time," The American Historical Review 124, no. 5 (December 2019): 1681-1688. On the spatial politics of Italian colonial racial schema, see Mia Fuller, "Preservation and Self-Absorption: Italian Colonisation and the Walled City of Tripoli, Libya," Journal of North African Studies 5, no. 4: 121154. ? 
4. Jemima Pierre, "Race in Africa Today: A Commentary," Cultural Anthropology 28, no. 3 (2013): 548.

5. Pierre, "Race in Africa Today," 549.

6. Leon Carl Brown, "Color in Northern Africa," Daedalus 96, no. 2 (1967): 464.

7. Steve Garner, Whiteness: An Introduction (New York: Routledge, 2007), 3.

8. Veronica Watson, Deirdre Howard-Wagner, and Lisa Spanierman, introduction to Unveiling Whiteness in the Twenty-First Century: Global Manifestations, Transdisciplinary Interventions, ed. Veronica Watson et al. (London: Lexington Books, 2015), xii. ?

9. Garner, Whiteness, 1.

10. Pierre, "Race in Africa Today," 549.

11. Sara Ahmed, "A Phenomenology of Whiteness," Feminist Theory 8, no. 2 (2007): 150.

12. In part, this kind of inquiry aligns with Raka Shome's comparative work on whiteness in the US and in India, where she is especially concerned with the operations of "disembodied whiteness." She explains, "Whiteness ... is not merely a discourse that is contained in societies inhabited by white people; it is not a phenomenon that is enacted only where white bodies exist. Whiteness is not just about bodies and color, but rather more about the discursive practices that, because of colonialism and neocolonialism, privilege and sustain the global dominance of white imperial subjects and Eurocentric worldviews." See Raka Shome, "Whiteness and the Politics of Location: Postcolonial Reflections," in Whiteness: The Communication of Social Identity, ed. Thomas K. Nakayama and Judith N. Martin (Thousand Oaks: SAGE Publications, 1999), 108-111. ?

13. Ahmed, "A Phenomenology of Whiteness," 153-54.

14. Ismael Montana, The Abolition of Slavery in Ottoman Tunisia (Gainesville: University Press of Florida, 2013).

15. Benjamin Claude Brower, "Rethinking Abolition in Algeria: Slavery and the 'Indigenous Question,'" Cahiers d'Études Africaines 49, no. 3 (2009): 805; Soha El Achi, "Children and Slave Emancipation in French Algeria and Tunisia (1846-1892)" (PhD diss., Georgetown University, 2017).

16. Amal Altaleb, "The Social and Economic History of Slavery in Libya (1800-1950)" (PhD diss., University of Manchester, 2015).

17. Eve Troutt Powell, A Different Shade of Colonialism: Egypt, Great Britain, and the Mastery of the Sudan (Berkeley: University of California Press, 2003), 66. P

18. Chouki El Hamel, Black Morocco: A History of Slavery, Race, and Islam (New York: Cambridge University Press, 2013), 264. ?

19. E. Ann McDougal, "Living the Legacy of Slavery: Between Discourse and Reality," Cahiers d'Études Africaines 45, no. 179/180 (2005): 963.

20. Ghislaine Lyon, "Slavery, Exchange and Islamic Law: A Glimpse from the Archives of Mali and Mauritania," African Economic History 33 (2005): 121-122; Bruce Hall, "The Question of 'Race' in the Pre-Colonial Southern Sahara," Journal of North African Studies 10, no. 3-4 (2005): 351-352. D

21. John O. Hunwick, "Islamic Law and Polemics Over Slavery in North and West Africa, 16th-19th Century," in Slavery in the Islamic Middle East, ed. Shaun Marmon (Princeton: Markus Wiener, 1999), 43-68.

22. Chouki El Hamel, Black Morocco, 9.

23. I find it particularly compelling, for example, to imagine that if the Arabic-speaking immigrants in the US in this period litigating their racial status in order to gain citizenship had been from what is now Algeria or Morocco, they may have claimed African descent, which would have produced a different legal legacy. 
24. Bruce Hall, "The Question of 'Race' in the Pre-Colonial Southern Sahara," Journal of North African Studies 10, no. 3-4 (2005): 340.

25. El Hamel, Black Morocco, 94-97 and 301.

26. See for example John O. Hunwick, "A Region of the Mind: Medieval Arab Views of African Geography and Ethnography and Their Legacy," Sudanic Africa 16 (2005): 103-136.

27. Afifa Ltifi, "Black Tunisians and the Pitfalls of Bourguiba's Homogenization Project," POMEPS Studies 40 (June 2020): 69-72.

28. I want to underscore the tenuousness and complexity of conceptions of Arabness in North Africa, which ultimately goes beyond the scope of this entry. For a brief and illuminating discussion of this term outside of its well-trodden geographies, see Mandana Limbert, "Caste, Ethnicity, and the Politics of Arabness in Southern Arabia," Comparative Studies of South Asia, Africa and the Middle East 34, no. 3 (2014): 590-598.

29. Ali Abdullatif Ahmida, ed., Bridges Across the Sahara: Social, Economic and Cultural Impact of the Trans-Saharan Trade During the 19th and 20th Centuries (Newcastle upon Tyne: Cambridge Scholars Publishing, 2011).

30. Ghislaine Lydon, On Trans-Saharan Trails: Islamic Law, Trade Networks, and Cross-Cultural Exchange in Nineteenth-Century West Africa (New York: Cambridge University Press, 2009); Ghislaine Lydon, "Writing Trans-Saharan History: Methods, Sources and Interpretations Across the African Divide," Journal of North African Studies 10, no. 3-4 (2005): 293-324; Tara Deubel, Scott Youngstedt, and Helen Tissieres, eds., Saharan Crossroads: Exploring Historical, Cultural, and Artistic Linkages Between North and West Africa (Newcastle upon Tyne: Cambridge Scholars Publishing, 2014). See also the Saharan Crossroads program that the American Institute for Maghrib Studies (AIMS) funds alongside the West African Research Association (WARA) and the Saharan Studies Association (SSA), http://aimsnorthafrica.org/saharancrossroads < http://aimsnorthafrica.org/saharan-crossroads>. ?

31. In thinking through the racialization of "natal claims" to particular geocultural formations, I am borrowing here from Su'ad Abdul Khabeer, who has explicated the processes through which "in U.S. American Muslim discourse, Blackness often can make no natal claim to an 'Islamic East.'" See Su'ad Abdul Khabeer, Muslim Cool: Race, Religion, and Hip Hop in the United States (New York: NYU Press, 2016), 80.

32. Ahmed, "A Phenomenology of Whiteness," 150.

33. It remains to be seen whether Amazigh nationalist narratives that highlight continuities of language and culture between indigenous communities throughout northern and Saharan Africa can disrupt normative North African practices of whiteness. I'm thinking of Instagram accounts, for example, that are intentional about portraying a spectrum of different bodies, skin colors, hair, and locale in order to narrate an Amazigh / Kel Tamasheq indigeneity (see, for example, https://instagram.com/Amazigh_nation < https://instagram.com/Amazigh_nation> ). I wonder to what extent these representational practices are disruptive, or if they are rather more akin to the diversity discourses of liberal white humanism in other contexts.

34. Houria Bouteldja, Whites, Jews, and Us: Toward a Politics of Revolutionary Love (South Pasadena: Semiotext(e), (2016), 29.

35. Mariam Nabbout, "Thanks for the Ramadan Comedies, But Enough with the 'Blackface,'" Stepfeed, May 14, 2019, https://stepfeed.com/thanks-for-the-ramadan-comedies-but-enoughwith-the-blackface-0576 < https://stepfeed.com/thanks-for-the-ramadan-comedies-butenough-with-the-blackface-0576> ; Hana Al-Khamri, "The Outrageous Racism that 'Graced' Arab TV Screens in Ramadan," Aljazeera, July 1, 2018, https://www.aljazeera.com/indepth/opinion/outrageous-racism-graced-arab-tv-ramadan180616134620046.html < https://www.aljazeera.com/indepth/opinion/outrageous-racismgraced-arab-tv-ramadan-180616134620046.html> ; Harakat Tanweer, Press Release, May 8, 2019, https://www.facebook.com/Libyatanweer/photos/a.346642885450494/2215721838542580/? type $=3 \&$ theater $<$ 
https://www.facebook.com/Libyatanweer/photos/a.346642885450494/2215721838542580/?

type=3\&theater $>$. ?

36. Powell, A Different Shade of Colonialism, 186, emphasis added.

\section{Author Information}

\section{Leila Tayeb}

Leila Tayeb is a Humanities Research Fellow at NYU Abu Dhabi focused on performance and politics in North Africa. She earned her PhD in Performance Studies from Northwestern University in 2018. Tayeb's current book project is an ethnography exploring political contestation through sound in urban Libyan daily life during the years after 2011. Her writing has appeared in the Arab Studies Journal, Communication and the Public, and the Journal of North African Studies, among others. She is a founding editorial collective member of Lamma: A Journal of Libyan Studies.

View all of Leila Tayeb's articles.

\section{Article details}

Leila Tayeb, "What is Whiteness in North Africa?," Lateral 10.1 (2021).

https://doi.org/10.25158/L10.1.20

This content is licensed under a Creative Commons Attribution-NonCommercial 4.0 International License. Copyright is retained by authors.

Lateral is the peer-reviewed, open access journal of the Cultural Studies Association.

ISSN 2469-4053 